\title{
When Mind and Memory Flee ...: Hymns and ministry to people with dementia
}

\author{
Graham D. S. Deans
}

Rev Dr Graham Deans was formerly Minister at Aberdeen: Queen Street.

\section{Introduction}

Ministering to people who have reached that stage of life when 'mind and memory flee" presents serious challenges which cannot be ignored.

This paper also draws on the author's experiences as a part-time Chaplain to a local hospital in which worship amongst geriatric patients (many of whom suffered from dementia) was conducted regularly (but informally) by clergy and volunteers from local churches. In such circumstances it was vitally important to 'sing something simple' which even the most confused of elderly patients could still understand, and to which some at least could actually respond.

\section{What is 'dementia'?}

The Oxford Reference Dictionary (1986) defines 'dementia' as 'insanity with loss of intellectual power due to brain disease or injury'. This is hardly the most sensitive or objective definition of a distressing condition which is deeply disturbing not only for sufferers, but also for their relatives and carers. By far the most common type of 'dementia' is Alzheimer's disease. This accounts for some $60-70 \%$ of cases, and one of the earliest symptoms of this debillitating disease is loss of short-term memory. This is usually masked by the occurence of forgetfulness which is thought to be a normal part of the natural ageing process - and it it this which makes an accurate diagnosis notoriously difficult. The disease is characterised by changes in nerve cells and neurotransmitter levels, as well as destruction of synapses, and as the disease progresses, memory loss becomes more

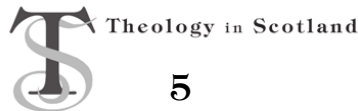




\section{Hymns and ministry to people with dementia}

and more profound, ${ }^{2}$ and can become deeply disorientating. Yet when the disease is in its early stages, sufferers can be remarkably adept at disguising the seriousness of what is happening to them, by changing the subject when conversations run into difficulty, or in making all manner of plausible excuses for their forgetfulness or their inabilty to understand what they may be reading or attempting to follow when watching television. In the course of a ministry of forty years, I have lost count of the times I have heard the complaint that sufferers were wearing the wrong glasses, and were unable to read because the print was allegedly getting smaller, or to identify characters when they experienced difficulty in recognising the faces of people appearing in TV programmes.

At the risk of over-simplification, 'dementia' may be regarded as a disordered state of mind; and since most sufferers tend to be over the age of 65 when this condition is finally diagnosed, they are often referred to as 'the confused elderly'.

\section{Who are affected by dementia?}

The patients to whom I ministered as a Chaplain fell broadly into the following categories:

- those disabled by strokes, and who had serious problems with mobility (because of paralysis) and communication (because of aphasia ${ }^{3}$;

- those suffering from progressive degenerative diseases such as Alzheimer's, and whose decline into mental confusion was gradual but inevitable and, sadly, irreversible, even though they still retained some periods of lucidity, but with a seriously limited attention span;

- those with unimpaired intellectual facilities but whose additional serious disabilities (caused by, e.g., multiple sclerosis, Parkinson's, or advanced motor neurone disease) prevented them from speaking - leading to the mistaken assumption on the part of visitors, carers, and even nursing staff that they had lost all intelligence;

- those so heavily sedated by drugs designed to curb aggression and/or relieve pain, that they appeared to be in a persistent vegetative state, in which they remained until death.

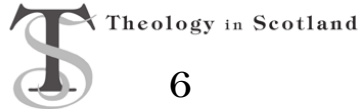




\section{Hymns and ministry to people with dementia}

With all but that final group, I found it was possible to have some meaningful contact, and to build up relationships. Many were still aware of their spiritual needs, and continued to appreciate the simple services of worship conducted in the hospital wards. Some, when taken to worship alongside the regular congregation in the local parish church, found the experience tremendously enriching and rewarding, and would talk about it for days afterwards. What invariably made the greatest impact on them was the singing of familiar hymns.

\section{The impact of hymn singing}

It is too easy in a 'post-Christian' society to underestimate the extent of residual faith among elderly people, who may have subconsciously learned by heart a core repertoire of hymns (and songs) in childhood. When patients sang these again, confusion seemed to disappear, and it was as if they were part of the 'real' world of lucidity and comprehension once more. Their moments of transcendence were, however, transitory. Experience came to suggest the following possible reasons as to why hymn singing seems to cause people (at least temporarily) to 'blossom and flourish': ${ }^{4}$

- Nostalgia is a good servant but a bad master. While 'nostalgia therapy' can successfully re-awaken dormant feelings of comfort, security, and stability, such as (rightly or wrongly) were associated with a happier bygone age, it should be used with caution, as its misuse can obstruct and hinder real spiritual growth.

- Residual memory: The most precious values of any religious community which are taught with diligence and enthusiasm tend to become so over-familiar in one's formative years that they are virtually impossible to erase. Hymns can make their way into our minds because of the frequency with which they are sung, to the extent that they are not easily disentangled from our beings. Whatever else is lost from memory, hymn lyrics (and their accompanying tunes) somehow contrive to remain there.

- The role of familiarity: People tend to recognise familiar things most readily - even when they encounter them 'out of context'. One

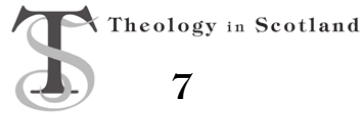




\section{Hymns and ministry to people with dementia}

is almost instinctively comfortable in familiar surroundings, in which familiar sights, sounds, faces, and phrases are instantly recognisable. But with dementia sufferers, this may not be the case, as they quite literally find themselves 'out of their comfort zone'. ${ }^{5}$ And when it comes to encountering new or unfamiliar hymns, they may well find that they equally lost, as they are unable to process the information. ${ }^{6}$

\section{Stages in remembering}

Generally speaking, it is claimed that the process of remembering involves three main stages:

- Registration: It is this first stage which causes most problems for confused elderly people; and this is clearly linked to the proverbial difficulty of attempting to teach an old dog new tricks. This is touched on by Daniel Letivin when he calls attention to the fact that researchers point to the teenage years as the turning point for musical preferences. It seems to be around the ages of 10-11 that most children take on a real interest in music, even if that did not manifest itself earlier. ${ }^{7}$ While there does not seem to be a 'cut-off point' for acquiring new tastes in music, most people appear to have formed their tastes by the ages of 18-20. It is not clear why this is so, but it is clear that in general people do become less open to new experiences as they age. There are similarly critical periods for acquiring new skills, such as learning a new language. ${ }^{8}$ Since learning the words and music of 'new' hymns can be equally difficult, pastoral sensitivity dictates that, more often than not, worship leaders are constrained to select only familiar, tried and tested texts and tunes in order to communicate effectively.

- Retention: Only that which has initially registered can be retained (and retrieved). The more frequently memories are re-lived, repeated, and rehearsed, the more likely it is that they will remain for life. The process is often aided by some of the most obvious features of both poetry and hymnody, such as rhythm, repetition, and rhyme; of these it is generally agreed that rhythm is the most important therapeutic factor, while rhyme (far from being frivolous) is a particularly potent aide-memoire. Thus older people

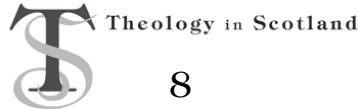




\section{Hymns and ministry to people with dementia}

can often vividly recollect memories from their earliest days (when things like multiplication tables were almost ritually and rhythmically 'drummed' into them), because these have been lodged in their psyche for so much longer. Even those memories that may be lost temporarily can prove to be recoverable. What is not possible, however, is to retrieve or recall memories that have neither registered successfully in the first place, nor have been retained.

- Retrieval: Even in cases of almost total amnesia (one of the most famous being that of the musician Clive Wearing [b. 1938], who suffered a catastrophic loss of brain function as a result of a virus that attacked his central nervous system), music can still communicate. Wearing could still sight-read music, play piano and organ, and conduct a choir perfectly - but could not recall having done so. ${ }^{9}$ Similarly with the Russian composer Shebalin (1902-63), who suffered a severe stroke which deprived him of his ability to speak, yet was still able to compose brilliant musical works, and correct the compositions of his students. ${ }^{10}$ One patient I encountered could sing perfectly and very loudly in tune, but since he could reproduce no words he was thought by others to be disruptive - but he was probably making his own distinctive contribution to the kind of service of worship with which he had once been so familiar. Clearly it still resonated powerfully with him (although it is difficult to say with certainty what it actually meant to him).

'Retirement' from regular and active participation in the Church's worship because of the enforced 'exile' of being housebound, hospitalised, or institutionalised means that many of the elderly population are effectively marginalised. They have no real say in the preparation or publication of new liturgical materials, and very few have the opportunity to contribute to a ministry of writing or composing 'in age and feebleness extreme'. ${ }^{11}$

\section{The therapeutic value of hymn singing}

Rhythm is probably the most important factor here. It is a recurring theme in Anthony Storr's Music and the Mind, first published in 1993. The title

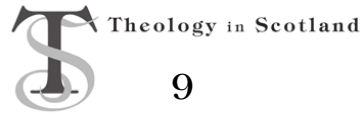


page includes a quotation from one John Logan (1744-88): 'Music's the medicine of the mind.' 12

Storr states that because music affects people physically, it is often used when groups of people are performing repetitive physical actions which do not require a great deal of thought. Working songs which help to alleviate the boredom of these actions, and assist in the co-ordination of these actions when performed together rhythmically (e.g. in an agricultural or industrial setting).$^{13}$ It has been alleged that singing together increases efficiency, but this appears to be unproven, even if it does enhance morale and foster a sense of belonging. There is, however, evidence that with certain other repetitive tasks which do require some mental effort and concentration, (background) music can prove counter-productive; the example he cites is that of typing, where music appears to increase the number of errors. ${ }^{14}$ (Interestingly, it was an alarming increase in typographical errors that alerted the novelist Sir Terry Pratchett to the fact that something was starting to go very seriously wrong with him. Formerly he had been word-perfect.)

Storr goes on to claim that rhythmic music is an agent of order. Rhythm is rooted in the body more so than melody or harmony; and the following quotation from the violinist Sir Yehudi Menuhin may be helpful:

Music creates order out of chaos; for rhythm imposes unanimity upon the divergent; melody imposes continuity upon the disjointed, and harmony imposes compatibility upon the incongruous. ${ }^{15}$

Nevertheless it is the rhythmic aspect of music that has long been recognised as an agent of order and of healing. Great composers like Haydn have displayed an almost obsessional preoccupation with order and of the need to create it ${ }^{16}$ and are rarely satisfied until they believe they have succeeded in doing so. Even the most disturbed of minds seem to crave order. Ian Mackenzie recalled an experience when with two friends he attended a most cacophonous performance of a play at the Edinburgh Festival Fringe. At the interval one of them sighed deeply and said, 'I have dispeace. Can we go?' They left, and Mackenzie took them to the nearby St Giles' Cathedral where he was the assistant organist. In the dark shadows of the building, he went to the organ loft and played Bach. 'Healed, we took coffee nearby and parted for the night.' ${ }^{17}$ The 'inbuilt snag' that Mackenzie felt with that illustration was that it appeared to

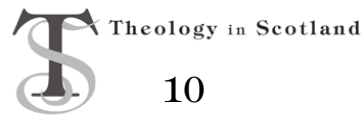




\section{Hymns and ministry to people with dementia}

confirm the stereotyped view of Bach as 'sucky blanket material for distressed persons of religious inclination' and that 'truth is to be found in the classical rather than the romantic muse.' ${ }^{18}$

Mackenzie's illustration - and his attendant warning - are significant. It is not surprising that church leaders have doubted whether the feelings that music arouses are genuinely religious; and as Anthony Storr comments, 'Music's power to fan the flame of piety may be more apparent than real; more concerned with enhancing group feeling within the congregation rather than promoting the individual's relationship with God. ${ }^{19}$ It is true that music can sometimes do no more than create a 'feelgood factor' and that hymn singing can foster a sense of belonging even amongst people who do not believe what they are singing, or subscribe to the faith that the words profess. After all, 'music is not a belief system' even if it does enrich human life, and is, as some may think, to be regarded as 'an irreplaceable, undeserved, transcendental blessing' ${ }^{20}$ or as a gift of God. ${ }^{21}$

Nevertheless, it may be the answer to the prayer of John Greenleaf Whittier that God might

Take from our souls the strain and stress, And let our ordered lives confess The beauty of Thy peace. ${ }^{22}$

\section{Hymns for those who care for people with dementia}

A contemporary hymn writer notes that

Some of our hymns on ageing and dementia, for example, may not speak to the people experiencing these (sc. difficulties) themselves, but to those who love and care for them. I think that this is a tension that we have not fully resolved, but at the same time, hymns which were 'new' in my youth are now becoming classic. ${ }^{23}$

Those who care, often invisibly and unnoticed, for people with dementia may be helped by the inclusion of suitably supportive hymns in regular congregational worship; examples include "When Our Caring Love Wears Thin" (Marjorie Dobson), "When Memory Fades and Recognition Falters" (Mary Louise Bringle), "With Thoughts That Wander, Minds Feel Frail"

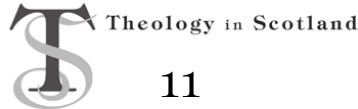




\section{Hymns and ministry to people with dementia}

(Andrew Pratt), "When Our Confidence is Shaken" (Fred Pratt Green) and "The One Who Longs to Make Us Whole" (Edith Sinclair Downing). ${ }^{24}$

\subsection{When Our Caring Love Wears Thin (Marjorie Dobson)}

This text appears in Singing the Faith (622), ${ }^{25}$ and in a recently published collection, Hymns of Hope and Healing (2017) edited by Jan Berry and Andrew Pratt, with Janet Eldred and Anne Sardeson, ${ }^{26}$ where it is described as 'a hymn for carers' as well as in the author's own collection Multi-coloured Maze. ${ }^{27}$ Though specific to the experience of carers, Marjorie's words seem to inhabit the same emotional world of struggle, fear and pain found in Jesus' prayer time in the Garden of Gethsemane, especially as re-told in the Gospel of Matthew 26:36-54. It takes us into an area of personal concern and experience rarely touched upon, at least so explicitly, in other hymns. It might be felt suitable for a service remembering those who have died in recent months; or for a service in which those who care, either as individuals or from within the caring professions, are the focus for reflection. Marjorie Dobson indicates, in her collection Multi-coloured Maze, that the last verse of the hymn may be omitted if felt to be inappropriate to the occasion.

She writes of those who care for relatives or friends out of duty or a love that leaves no other option. 'Even the most dedicated of carers have their own needs too, and the stress and strain of loving concern can be so overwhelming that it leads to resentment and frustration.' There is an inner turmoil also, Marjorie observes, as we struggle to understand or balance how we should feel about a loved one's prolonged illness or that final release both for patient and carer. Reflecting more recently on these words, she writes: 'In the last few years I've become a carer myself ... Although my text was based more on other people's experience, I now know from my own the truth of the words I'd written.' ${ }^{28}$

\subsection{When Memory Fades and Recognition Falters (Mary Louise Bringle)}

This text was written by Mary Louise Bringle for a friend's mother (June K. Berg) who suffered from Alzheimer's disease for twelve years before her death occurred in October 2008. Written specifically for the tune FINLANDIA, its rhythmic and melodic solemnity are well suited to the honesty of hesitation and hope expressed in the words. Dr Bringle's sensitivity to this painful passage of life's journey through the shadows to

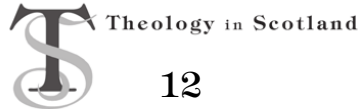




\section{Hymns and ministry to people with dementia}

its inevitable conclusion is combined with a concern to remember and to affirm the presence of God in the midst of this difficult situation. ${ }^{29}$

One of the most significant gifts of this text is how the hymn writer gives dignity and theological meaning to God's "aging [sic] servant." In spite of the present situation, God's "goodness lives unfading," a statement in antithesis to fading memories in the first line of stanza one. Present suffering becomes more bearable and gains perspective when we draw upon memories of the past and hopes for future resolution. Then the poet, in a richly reverberant phrase, seizes on a central thought that places into context the condition of one suffering from loss of memory and dignity: "no valued deed will ever be undone." 30

The reference in the hymn's first line to how 'recognition falters' raises the issue of a common, but distressing condition that affects many dementia sufferers (and has implications for their carers) and that is the problem which is termed prosopagnosia. This denotes the inability to recognise the faces of people with whom they were once very familiar.

It was Groucho Marx who once said, 'I never forget a face, but in your case I'll be glad to make an exception. ' ${ }^{31}$ But for those who suffer from prosopagnosia this is no laughing matter, and can be profoundly distressing for friends and relatives when they are not recognised. One of my early encounters with this problem concerned a former office-bearer who had developed Alzheimer's disease, which left her feeling so lost and confused that she had to accept full-time residential care. Pastoral visits became difficult as conversations quickly dried up. On one occasion, in what proved to be a spectacular failure to engage her interest, I took with me as a visual aid, a group photograph of office-bearers in which she featured, and which had been taken shortly before she became ill. But while she still continued to recognise me as her Minister, she was completely unable to identify any of her fellow officebearers in that group photograph. The only two faces that she could recognise were her own and mine. This frustrating condition has been well documented, ${ }^{32}$ and was illustrated by the example of a war veteran who had sustained, but survived a bullet wound to the brain during the battle of Smolensk in $1943 .^{33}$ Sufferers (who may not have experienced injuries as traumatic as war wounds) can see, but cannot understand whom or what they see, as their

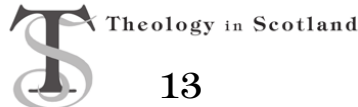


damaged brains fail to process the information correctly. The inevitable consequences are that when sufferers give vent to their frustrations, their relatives, friends, and carers take offence, and relationships break down.

For such people, familiar hymns can often function like familiar friends. Listeners may respond well to the words and to the music, and may even be able to sing them perfectly. But if one were to ask why they enjoyed such experiences, the likelihood is that even the most sensitive enquiry would elicit a blank response. There is perhaps here also a warning for well-meaning revisers who tamper with familiar hymn texts to the extent that their appearance or 'face' has been changed out of all recognition. The counter-argument is of course that it is a fact of life that facial appearances do change as people age. Nevertheless one can understand the protests of people who react to hearing such changes which may well have altered not just their perception of a familiar hymn, but also its doctrinal stance: 'Why are they singing the wrong words?' and/or 'Why are they singing the wrong tune?'

\subsection{With Thoughts That Wander, Minds Feel Frail (Andrew Pratt)}

Another hymn that may be helpful when one contemplates the difficulties in living with or ministering to someone who suffers from prosopagnosia is Andrew Pratt's reflection on ageing, beginning, 'With thoughts that wander, minds feel frail'.${ }^{34}$ I was particularly struck by the third stanza:

Yet God, who knew us at our birth,

still folds in love and grace,

has brought us to this present day,

still knows each name and face.

The hymn ends with a powerful affirmation of faith:

And to this God we offer all

In faithful love and praise

Through singing laughter, wringing tears,

Through every changing phase.

In correspondence with the author, Dr Pratt stated that he had not written this text with the condition of prosopagnosia specifically in mind; indeed, while he was 'obviously aware of the condition', he was unfamiliar with

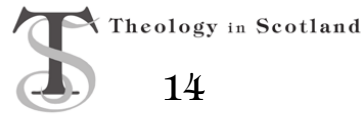




\section{Hymns and ministry to people with dementia}

the technical term for it. He said that since retiring he had become increasingly aware of the fact that we are not what we once were. As to what motivated much of his writing, he pointed to 'empathy, experience, and imagination' and affirmed that 'when all others forget and we forget them God knows us all [and] calls us by name, as it were. And that's worth "faithful love and praise". 35

\subsection{When Our Confidence Is Shaken (Fred Pratt Green)}

This hymn was written in 1970 and was published the following year with the title "A Mature Faith" ${ }^{36}$ Although not specifically written with care for dementia sufferers in mind, the first verse nevertheless seems particularly relevant, when the author speaks of how 'the spirit in its sickness seeks but cannot find a cure'. In stanza two, which theologically incorporates the neoplatonic idea of a return to God as the limit of reason, ${ }^{37}$ the author confronts the ultimate doubts: 'our research leads us to the ultimate unknown'. In a bold statement, Pratt Green concludes the stanza:

Faith must die, or come full circle

to its source in God alone.

Stanza three encourages us to maintain the 'discipline of praying, when it's hardest to believe'. He also speaks of 'the drudgery of caring' which doubtless affects all who are closest to those who grieve for the diminishing world of sufferers. Nevertheless, 'Faith maturing, learns acceptance of the insights we receive' from them in their rare, but precious moments of lucidity.$^{38} \mathrm{C}$. Michael Hawn writes of the fourth stanza,

The final stanza states unequivocally: 'God is love, and thus redeems us in the Christ we crucify'. The author concludes by praying that even in a crisis of faith:

\section{May we in this faith maturing be content to live and die!}

This is an excellent example of congregational song that speaks to a world of what may seem to us to be systemic uncertainty. While earlier hymns often were inspired by personal loss or tragedy, we now move into a realm of pervasive fear and doubt. When all is

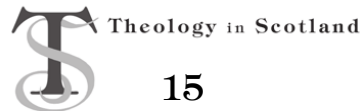




\section{Hymns and ministry to people with dementia}

said and done, we return to faith: "Now faith is the assurance of things hoped for, the conviction of things not seen" (Hebrews $11: 1) .{ }^{39}$

\subsection{The One Who Longs to Make Us Whole (Edith Sinclair Downing)}

The one who longs to make us whole is waiting to embrace our broken lives, so we can know the power of healing grace.

God's love surrounds our suffering, and keeps us through the night;

God helps us bear our deep despair till we see morning light.

The one who saves us from ourselves is waiting to release our hearts from chains of self-reproach and failure to find peace.

When harmful habits leave us bruised, distraught by inner pain, God comes to us through trusted friends, and helps us hope again.

The one who understands our need accepts us as we are; and, like a loved one, welcomes us when we have wandered far.

God never says we come too late to be forgiven, free, but promises we can become the self we're meant to be. ${ }^{40}$

Edith Sinclair Downing (1922-2016), CH4 71941

Edith Downing, a graduate of the University of Chicago and of Trinity Lutheran Seminary, was a cellist and organist who came late to the ministry of hymn-writing; her first text was written when she was in her sixties. She drew her inspiration from Scripture and also from her 
considerable experience of life. Her first collection of hymns, A Season of Clear Shining was published in 1998 by Selah Publishing Co. (Pittsburgh). She directed youth choirs for many years, and was still playing the organ at her local church until she was well into her eighties. ${ }^{42}$ The hymn certainly has something valuable to say (especially in its first stanza) to those who have the responsibility of caring for a friend or relative suffering from Alzheimer's disease - and it ends on a hopeful note for those who are able to put their trust in the promises of God. (I can't help feeling that it resonates powerfully with Beethoven's dying conviction - 'I shall hear in Heaven!' ${ }^{43}$ )

\section{The challenge of new hymns}

Generations inevitably rise and pass away; but in contrast to the fixed canon of Holy Scripture, the basic 'core repertoire' of hymnody is subject to constant revision and change. Few hymn writers - not even those who have a fine conceit of their abilities - can truthfully echo the Classical poet Horace's claim, 'Exegi monumentum aere perennius' ${ }^{44}$ and expect their work to last, boldy asserting as he did, 'non omnis moriar'. ${ }^{45}$ The hymnwriter Elizabeth Cosnett remarked (at a Hymn Society conference) that in order to get a new hymn accepted, it has to displace an old one. This rather disconcerting fact (which some regard as being as serious as the Deuteronomic prohibition of the removal of their neighbour's landmark ${ }^{46}$ ) may appear to confirm the common (mis-)perception that new hymns are forced upon the Church; but the reality is that 'In its struggle to formulate the faith and serve the coming Kingdom amidst the ambiguities of contemporary life, the church calls for new songs to refresh it and call it forward ${ }^{47}$ because each generation demands its own hymn book, ${ }^{48}$ and 'the Church in its worship must be contemporary. ${ }^{49}$ We dare not forget the Scriptural injunction to sing a new song to the Lord (Psalms 96:1, 98:1, and 149:1). But it is also worth remembering that for those who are unable to learn new facts because the severity of their condition prevents them from doing so, this is an extremely difficult, if not impossible task. New hymns are not part of their 'retained memories'; if they fail to register in the minds of dementia sufferers, it cannot be expected that they will be able to recall, retrieve, or reproduce them in the way that they may still be able to do with their most familiar and favourite texts and tunes that were 'over-learned' in childhood. Those whose personal 'canon' of hymnody is

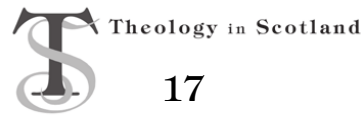




\section{Hymns and ministry to people with dementia}

effectively now closed (through no fault of their own) should not be banished to some kind of spiritual desert which is completely devoid of the trusted and cherished ancient landmarks of traditional hymnody. It is not just the verdict of literary or liturgical conservatism to say that this would be a mistake.

Nevertheless, if one cares to examine the vast output of two of the most prolific hymn writers, namely, Isaac Watts and Charles Wesley, one will soon realise that although much of what they wrote was in their own day and generation innovative and at the cutting edge, a great deal of their creative output was ephemeral, and that having served its immediate purpose, it must now be laid aside as worthless. ${ }^{50}$ Indeed, it has well been observed that 'If one glances over any eighteenth-century collection, it is impossible not to be stuck by the fact that the vast majority of the hymns contained in it are dead beyond redemption - no one could sing them now; and the proportion of hymns that have lasted is very small. ${ }^{51}$ Not even what Dr Millar Patrick describes as the authors' 'superlatively best' work ${ }^{52}$ is guaranteed to survive, since as Elaine Paige and Barbara Dickson have reminded us, 'nothing is so good it lasts eternally'. ${ }^{53}$ One might add that if a hymn is written in an unusual metre, or is never partnered with a truly great tune, it may neither 'catch on' nor succeed in becoming stored securely in the memories and hearts of the faithful, despite the literary excellence of the text. ${ }^{54}$ Time has not altered the relevance or the truth of those observations.

Storr has written about his impression that there is a discrepancy between interest and talent, which is encountered more in music than in any other discipline. ${ }^{55}$ (I certainly wish that I could play the piano and the organ much better than I can - and as a published hymn writer I envy those who can write good hymn texts and set them to better music than I can produce myself!) The sense of disappointment at not being able to pick up new tunes and to sing them to new words as easily as I feel I should is serious, and gives me cause for concern. One can feel a sense of alienation and isolation at being excluded from participation; how much more frustrating might it be for those whose abilities have been further compromised by aphasia and/or amusia that result from the damage that dementia inflicts upon their brains, and who find themselves even more confused by being in a completely unfamiliar spiritual setting? 


\section{Hymns and ministry to people with dementia}

\section{Conclusion}

The words and the music of Christian hymns are often far more potent than may be first apparent. As such, they are singularly under-rated vehicles of grace. Words absorbed (even 'over-learned') in one's formative years are strangely comforting when the end of life approaches - especially if this proves to be a time when people seek to return to the familiar surroundings of the faith of their forebears, and find themselves 'in quires and places where they sing, ${ }^{56}$ The music of hymnody is also a powerful means of non-verbal communication, which can help an otherwise confused worshipper to achieve brief, but priceless moments of transcendence. Thus the sensitive and judicious use of appropriate hymns can prove highly effective in contributing towards satisfying the immortal longings of even the most disturbed of human souls.

\section{Resources}

- https://www.sarum.ac.uk/wp-content/uploads/2017/01/Worship-andPeople-with-Dementia.pdf - from Methodist Homes together with the Christian Council on Ageing; includes worship and some hymn suggestions.

- https://worship.calvin.edu/resources/resource-library/christian-worshipexperiences-for-persons-with-dementia/ - an older American resource which contains useful, general background with much that is transferable.

\section{Acknowledgements}

I am grateful to Martin Leckebusch and the members of the Publications Committee of the Hymn Society of Great Britain \& Ireland for permission to publish this expanded version of one of their "Short Guides" (no. 27) on their website; and also to the Rev Professor Elsabé Kloppers who kindly read several draft versions of this article and offered a good deal of muchneeded constructive crticism and encouragement.

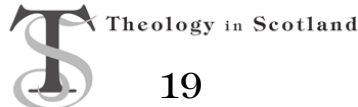




\section{Notes}

${ }^{1}$ From the last verse of James Montgomery's hymn, “According to Thy Gracious Word".

${ }^{2}$ See Daniel Levitin, This is Your Brain on Music: Understanding a Human Obsession (London: Atlantic Books, 2007), 231.

3 'Aphasia' has been defined as the partial or total loss of the normal ability to produce and understand speech as a result of brain damage caused by injury or disease.

${ }^{4}$ From the third verse of Walter Chalmers Smith's hymn, "Immortal, Invisible, God Only Wise".

5 The precise origin of the expression 'comfort zone' is notoriously difficult to trace, let alone to define. [Alasdair White, From Comfort Zone to Performance Management: Understanding Development and Performance (La Houlette, Belgium: White \& MacLean Publishing, 2008), 2]. It may be regarded as denoting a psychological state in which people are at ease in familiar surroundings, in which they experience low levels of anxiety and the minimum of stress (ibid.) Not all stress, however, is necessarily bad. Some separate it into 'eustress' which is good, such as one feels with joy, fulfilment, or satisfaction, and 'distress' which is damaging. [See John B. Cairns, Keeping Fit for Ministry (Edinburgh: Saint Andrew Press, 1988), 1.] Such 'distress' becomes more acute for people with dementia, who may suffer from 'topographical agnosia' which renders them unable to use visual cues that would normally guide them in a particular direction, and may even prevent them from being able to navigate around their own home (where they should feel comfortable). This condition is thought to be caused by lesions in the right posterior cingulate area of the brain [see Susan Perry, "Oliver Sacks describes his struggle with face blindness", https://www.minnpost.com/secondopinion/2010/08/oliver-sacks-describes-his-struggle-face-blindness/]. The inability to recognise places compounds the stress and discomfort experienced by those who feel lost and confused even in familiar surroundings when their sense of direction fails them.

${ }^{6}$ Stress can have the same effect - the mind begins to reject new information. People who are 'overloaded' tend not to take in very much of what is said to them, nor do they remember much of the rest. See Cairns, Keeping Fit for Ministry, 3.

${ }^{7}$ Letivin, This is Your Brain on Music, 231.

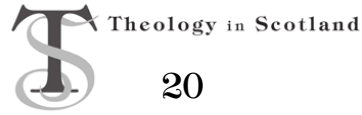




\section{Hymns and ministry to people with dementia}

${ }^{8}$ Ibid., 231-33.

${ }^{9}$ For further details, see Oliver Sacks, Musicophilia: Tales of Music and the Brain (London: Picador, 2011), 201-31; he notes that Wearing's wife (with whom he corresponded) has also written about her husband's condition [Deborah Wearing, Forever Today: A Memoir of Love and Amnesia (London: Doubleday, 2005)].

${ }^{10}$ See Anthony Storr, Music and the Mind (London: HarperCollins, 1992), 36, and Sacks, Musicophilia, 233 note.

${ }^{11}$ Charles Wesley was a notable exception: this is a quotation from his last hymn, dictated to his wife shortly before he died in 1788 .

12 This John Logan has proved impossible to identify. It is, however, certain that he was not the same Logan as the one associated with the composition and revision of some of the Scottish Paraphrases (1781).

${ }^{13}$ Letivin makes the point that in order to be moved by music (physically and emotionally) it helps a great deal if the music has a predicable beat (This is Your Brain on Music, 170).

${ }^{14}$ Storr, Music and the Mind, 32.

${ }^{15}$ Cited ibid., 33.

${ }^{16}$ Ibid., 116.

${ }^{17}$ Ian Mackenzie, Tunes of Glory: What Music is Good Enough for God? (Edinburgh: Handsel Press, 1993), 126.

${ }^{18}$ Ibid., 126.

${ }^{19}$ Storr, Music and the Mind, 22.

${ }^{20}$ Ibid., 187 f.

${ }^{21}$ Ernest Edward Dugmore (1843-1925) claims in his hymn, "Almighty Father of All Things That Be" that 'the skilled musician's mystic art' is a gift of Divine origin (Church Hymnary, $4^{\text {th }}$ edition [Norwich: Canterbury Press, 2005], 497:3).

${ }^{22}$ From his hymn "Dear Lord and Father of Mankind" (Church Hymnary, $4^{\text {th }}$ edition, 485:5.)

${ }^{23}$ Jan Berry, "Broken Hopes, New Dreams", The Hymn Society Bulletin 22.2 (2018), 54-66. Citation from 64f. Berry is also one of the editors of Hymns of Hope and Healing (London: Stainer \& Bell, 2017), and it is to this book that she refers in her article.

${ }^{24}$ All with the exception of Dr Pratt's hymn, along with the two hymns quoted earlier in the paper, can be found in either Singing the Faith (Trustees for Methodist Church Purposes, 2011) or Church Hymnary, 4th edition, among other sources. Dr Pratt's text can be found in Hymns of Hope and Healing.

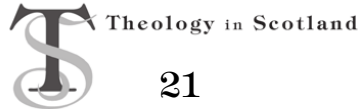




\section{Hymns and ministry to people with dementia}

25 Here it is set to a traditional nineteenth-century tune entitled CHARTERHOUSE by Alexander Samuel Cooper (1835-1900).

${ }^{26}$ In Hymns of Hope and Healing, it is set to a new tune by Ian Sharp (b. 1943) entitled GOD OF COMFORT.

${ }^{27}$ Marjorie Dobson, Multi-coloured Maze: Drama, Hymns, Prayers and Poems for Worship and Everyday Living (London: Stainer \& Bell, 2004).

${ }^{28}$ From http://www.singingthefaithplus.org.uk/?p=891.

${ }^{29}$ From Stanton Berg, "June K. Berg: A Journey Through Alzheimer's" published online on $23^{\text {rd }}$ January 2017 (https://www.junebergalzheimers. $\mathrm{com} /$ when-memory-fades-and-recognition-falters).

${ }^{30}$ Ibid.

${ }^{31}$ Oxford Dictionary of Quotations, $6^{\text {th }}$ ed. (Oxford: OUP, 2004), 516.10.

32 A. R. Luria, The Working Brain: An Introduction to Neuropsychology (London: Penguin, 1973), 126, 162, 238f.; Bryan Kolb and Ian Q. Whishaw, Fundamentals of Neuropsychology, $2^{\text {nd }}$ ed. (New York: Freeman, 1985), 214f. See also Oliver Sacks, The Man Who Mistook His Wife for a Hat (London: Picador, 2011). First published in 1985, this tells the story of an eminent but eccentric musician who was referred to Dr Sacks because he had become unable to identify the faces of his own pupils. Although at that stage this patient exhibited no signs of dementia (p. 10), he did suffer from diabetes, and was referred to Dr Sacks because it was thought that he might have had some kind of associated visual impairment. Yet his musical abilities remained unimpaired until his death, which was due to a massive tumour or degenerative process in the visual parts of his brain (p. 20). In a later publication, Dr Sacks conjectures that his patient may have suffered from an early, and primarily visual form of Alzheimer's (Musicophilia, 257). Interestingly, Sacks himself suffered from prosopagnosia (Perry, "Oliver Sacks describes his struggle with face blindness").

${ }^{33}$ Kolb and Whishaw, Fundamentals of Neuropsychology, 205; Luria, The Working Brain, $47 \mathrm{f}$.

${ }^{34}$ Jan Berry Andrew Pratt, et al., eds., Hymns of Hope and Healing: Words and Music to Refresh the Church's Ministry of Healing (London: Stainer \& Bell, 2017), no. 79 .

${ }^{35}$ E-mail to author, $26^{\text {th }}$ February 2018.

${ }^{36}$ From Richard Watson and Kenneth Trickett, eds., Companion to Hymns and Psalms (Peterborough: Methodist Publishing House, 1988), 389.

${ }^{37}$ Ibid.

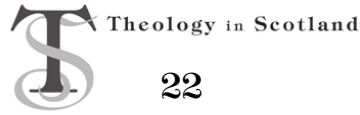




\section{Hymns and ministry to people with dementia}

${ }^{38}$ The comments at this point are my own.

${ }^{39}$ C. Michael Hawn, 'History of Hymns: "When Our Confidence Is Shaken", https://www.umcdiscipleship.org/resources/history-of-hymnswhen-our-confidence-is-shaken

${ }^{40} \mathrm{https}: / / \mathrm{www}$. youtube.com/watch? $\mathrm{v}=$ ggbgm75Wnts

${ }^{41}$ The copyright holder for this text cannot be traced.

${ }^{42}$ From https://www.selahpub.com/SelahPeople/Downing.html

${ }^{43}$ Attributed, but evidence is lacking.

${ }^{44}$ Quintus Horatius Flaccus, Odes, Book 3, no. 30, line 1. English translation: 'I have constructed a monument more enduring than bronze.' ${ }^{45}$ Ibid., Bk 3, no. 30, line 6. English translation: "Not all of me shall die". ${ }^{46}$ Deuteronomy 19:14.

${ }^{47}$ Douglas Galbraith, "Contemporary Worship and its Music", in With Strings and Pipe: New Essays in Church Music, ed. Gordon Graham (St Andrews: University of St Andrews Music Centre, 1994), 73-86. Citation from 78.

48 'The lapse of a generation, however, stales even the best of hymnbooks.' From James Moffatt and Millar Patrick, eds., Handbook to the Church Hymnary. Revised Edition with Supplement (London: Oxford University Press, 1935), xxx.

${ }^{49}$ A. Stewart Todd, "The Canticles and the People's Part in the Divine Service", in Handbook to the Church Hymnary, 3rd edition, ed. John M. Barkley (London: OUP, 1979), 44-54. Citation from 44.

${ }^{50}$ Millar Patrick, The Story of the Church's Song (Edinburgh: Church of Scotland Committee on Publications, 1947), 139. The use of the word 'worthless' may seem unduly harsh, but the reality is that 'truth often hurts'! ${ }^{51}$ Ibid., $180 \mathrm{f}$.

${ }^{52}$ Ibid., 138.

${ }^{53}$ From the song, "I Know Him So Well" written by Tim Rice, Benny Andersson and Björn Ulvaeus, for the musical Chess (1985). Paige and Dickson's recording is probably the best-known version currently available.

${ }^{54}$ One possible exception might be the hymn, "How Shall I Sing That Majesty" by John Mason (1646-94) which gained a new lease of life when it was coupled with the magnificent tune COE FEN by Kenneth Nicholson Naylor (1931-91), as in Church Hymnary, 4th edition, 128.

${ }^{55}$ Storr, Music and the Mind, 38.

${ }^{56}$ Book of Common Prayer (1662), Morning Prayer Rubric following the Third Collect. 